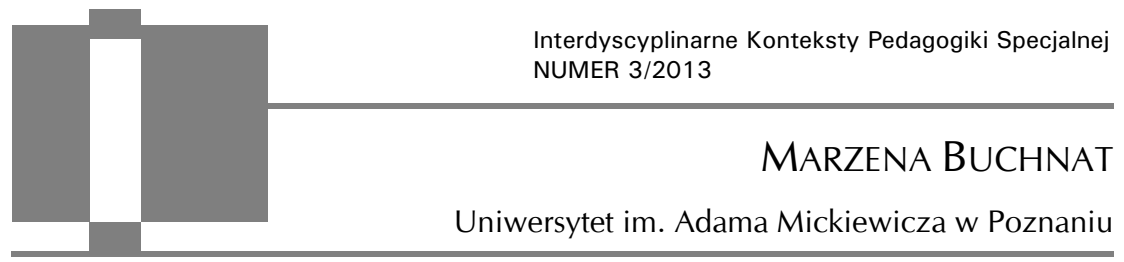

\title{
Metoda projektów płaszczyzną inkluzji dla dzieci z lekką niepełnosprawnością intelektualną
}

\begin{abstract}
Buchnat Marzena, The project method as the plane of inclusion for children with mild intellectual disabilities [Metoda projektów płaszczyzną inkluzji dla dzieci z lekką niepełnosprawnością intelektualną]. Interdyscyplinarne Konteksty Pedagogiki Specjalnej, nr 3, Poznań 2013. Pp. 31-44. Adam Mickiewicz University Press. ISBN 978-83-232-2721-2. ISSN 2300-391X.

The project method as a teaching method, which is based on activating teaching strategies, ensures holistic development of a child. It allows to select activities for children at different stages of development, stimulates thinking, teaches to put the newly acquired knowledge into practice and enables to learn through doing, which in particular raises the level of effectiveness of teaching children with mild intellectual disabilities. The joint teamwork of the whole class on the project helped them to enter the social life of the school, becoming a good plane of inclusion. However, according to the studies, the problem is the knowledge and awareness of possibility of applying this method by primary education teachers to support the school functioning of children with special educational needs including those with mild intellectual disabilities.
\end{abstract}

KEY WORDS: the project method, inclusion, a student with mild intellectual disability

Edukacja włączająca staje się faktem w naszych szkołach ogólnodostępnych, mimo że G. Szumski pisze: „nie jest ona nawet jednoznacznym terminem [...], co najwyżej zbiorem idei o różnym 
poziomie ogólności i z reguły słabo opisanych relacjach logicznych"1. Staje się coraz bardziej powszechna chociażby dzięki zmianom ustawodawczym, takim jak na przykład Rozporządzenie Ministra Edukacji Narodowej z dnia 30 kwietnia 2013 r. w sprawie zasad udzielania i organizacji pomocy psychologiczno-pedagogicznej w publicznych przedszkolach, szkołach i placówkach (Dz.U. z 2011 r. Nr 228). Inkluzja dzieci z niepełnosprawnością, w szczególności dzieci z lekką niepełnosprawnością intelektualną, wymaga jednak zastosowania odpowiednich metod pracy, które będą sprzyjały ich wchodzeniu w społeczną przestrzeń klasy. Uczniowie z lekką niepełnosprawnością intelektualną mają problemy z realizacją tych samych zadań co ich pełnosprawni rówieśnicy, a każda forma rywalizacji, czy to w obszarze nauczania, aktywności plastycznej, czy sportowej, w większości przypadków nie daje szans na odniesienie sukcesu. Taki sposób funkcjonowania tych uczniów często niestety prowadzi do ich marginalizacji, pozostawienia poza głównym nurtem życia szkolnego, a w skrajnych przypadkach wręcz do izolacji. Taki poziom funkcjonowania uczniów z lekką niepełnosprawnością intelektualną w nauczaniu ogólnodostępnym potwierdzają liczne badania ${ }^{2}$. Niestety przedstawione wyniki im-

1 G. Szumski, Wokót edukacji włączającej. Efekty kształcenia uczniów z niepetnosprawnościa intelektualna w stopniu lekkim w klasach specjalnych, integracyjnych i ogólnodostęnych, Wyd. APS, Warszawa 2010, s. 11.

2 M.in.: A. Brantley, E.S. Huebner, R.J. Nagle, 2002; J. Bąbka, 2003; M. Chodkowska, 2004; I. Chrzanowska 2002; K. Ćwirynkało 2003; Z. Gajdzic 2006; A. Głodkowska 1999; J. Lipińska-Lokś, 2004; J. Lipińska, A. Rogoża, 2003; S. Sadowska, 2006a, b; A. Zamkowska, 2008; G. Wiącek, 2005).

A. Brantley, E.S. Huebner, R.J. Nagle, Multidimensional Life Satisfaction Reports of Adolescents With Mild Mental Disabilities, „Mental Retardation” 2002, Vol. 40, No. 4; J. Bąbka, Psychospołeczne aspekty efektywności edukacji w systemie integracyjnym, [w:] Z. Kazanowski, D. Osik-Chudowolska (red.), Integracja osób niepetnosprawnych w edukacji $i$ interakcjach społecznych, Wyd. UMCS, Lublin 2003; M. Chodkowska, Socjopedagogiczne problemy edukacji integracyjnej dzieci z obciążeniami biologicznymi $i$ środowiskowymi, WSP TWP, Warszawa 2004; I. Chrzanowska, Uczeń z upośledzeniem umysłowym w szkole ogólnodostępnej, [w:] W. Dykcik, C. Kosakowski, J. Kuczyńska-Kwapisz (red.), Pedagogika specjalna szansą na realizacje potrzeb osób z odchyleniami od normy, Wyd. Nauk. PTP, Olsztyn-Poznań-Warszawa 2002; K. Ćwirynkało, Pozycja socjometryczna 
plikują konkluzję, iż szkoły ogólnodostępne nie zapewniają optymalnych warunków rozwojowych uczniom z lekką niepełnosprawnością intelektualną, przez co nie są $\mathrm{w}$ pełni gotowe do ich przyjęcia. Istotne wydaje się zatem określenie, jakie metody pracy będę sprzyjały włączeniu dzieci $\mathrm{z}$ niepełnosprawnością $\mathrm{w}$ funkcjonowanie w przestrzeni szkolnej.

Strategie kształcenia transmisyjnego wydają się mało odpowiednie, ponieważ oparte są na przekazie przez nauczyciela gotowej, uporządkowanej wiedzy o świecie, co w konsekwencji w dużej mierze utrwala bierność poznawczą ucznia. W strategii pracy nauczyciela przeważa koncentracja na zasobach wiedzy, a nie na sposobach jej osiągania. Następuje również oderwanie treści kształcenia od jej zastosowania w praktyce. Główną aktywnością charakteryzuje się nauczyciel, który przekazuje, utrwala i sprawdza treści kształcenia, natomiast uczeń staje się jedynie jej biernym odbiorcą̧

uczniów niepetnosprawnych a postawa nauczycieli wobec integracji, [w:] Z. Kazanowski, D. Osik-Chudowolska (red.), Integracja osób niepetnosprawnych w edukacji i interakcjach spotecznych, Wyd. UMCS, Lublin 2003; Z. Gajdzica, O wychowaniu i ksztatceniu dzieci o specjalnych potrzebach edukacyjnych w szkole ogólnodostępnej, [w:] J. Wyczesany, Z. Gajdzica, Uwarunkowania edukacji i rehabilitacji uczniów o specjalnych potrzebach rozwoju, Wyd. Nauk. Akademii Pedagogicznej, Kraków 2006; J. Głodkowska, Poznanie ucznia szkoły specjalnej, WSiP, Warszawa 1999; J. Lipińska, A. Rogoża, Stosunek $i$ zachowanie dzieci petnosprawnych wobec dzieci niepetnosprawnych w klasach integracyjnych, [w:] Z. Kazanowski, D. Osik-Chudowolska (red.), Integracja osób niepetnosprawnych w edukacji i interakcjach społecznych, Wyd. UMCS, Lublin 2003; J. Lipińska-Lokś, Psychospoteczne funkcjonowanie uczniów niepetnosprawnych w klasach integracyjnych, [w:] J. Bąbka (red.), Człowiek niepetnosprwny w różnych fazach życia, Wyd. „Żak”, Warszawa 2004; S. Sadowska, Jakość życia uczniów z niepetnosprawnościa intelektualna w stopniu lekkim, Oficyna Wydawnicza „Impuls”, Kraków 2006a; S. Sadowska, Szkolne stosunki interpersonalne w ocenach zadowolenia uczniów z niepetnosprawnościa intelektualna $w$ stopniu lekkim, „Szkoła Specjalna” 2006b, nr 4; A. Zamkowska, Psychospoteczne i edukacyjne funkcjonowanie ucznia z upośledzeniem umystowym w stopniu lekkim $w$ szkole ogólnodostępnej, [w:] Z. Gajdzica (red.), Wspólne i swoiste zagadnienia edukacji i rehabilitacji osób z upośledzeniem umysłowym, Oficyna Wydawnicza „Humanitas”, Sosnowiec 2008.

${ }^{3}$ Zob. m.in.: D. Gołębniak, G. Teusz, Edukacja poprzez język. O catościowym uczeniu się, Wyd. CDN, Warszawa 1999; Z. Kwieciński, Nieobecne dyskursy, Wyd. Nauk. UMK, Toruń 1991; D. Klus-Stańska, Konstruowanie wiedzy w szkole, Wyd. UWM, 
W związku z tym ocena pracy dziecka głównie oparta jest na jego możliwościach odtworzenia przerobionego materiału, z czym uczeń z lekką niepełnosprawnością intelektualną będzie miał oczywisty problem. Strategia ta nie sprzyja również zabezpieczeniu odpowiednich warunków do nauki dla dziecka z lekką niepełnosprawnością intelektualną, na przykład poznania polisensorycznego, łączenia teorii z praktyką, dostosowania tempa pracy itd.

Znacznie odpowiedniejszą wydaje się aktywizująca strategia kształcenia oparta na konstruktywistycznej teorii uczenia się. Strategia ta bazuje na podmiotowej interakcji ucznia i nauczyciela, dającej każdej ze stron poczucie bezpieczeństwa i sprawstwa4 ${ }^{4}$. Dominującą pozycję $\mathrm{w}$ relacji podmiotowej zajmuje uczeń, nauczyciel zaś wchodzi z nim okresowo w aktywny kontakt podczas epizodów wspólnego zaangażowania ${ }^{5}$. W aktywizującej strategii nauczania nauczyciel wspólnie z uczniem kreuje polszczyznę działań, dbając o zapewnienie optymalnych dla potrzeb dziecka warunków nauki, biorąc pod uwage jego zainteresowania, możliwości i oczekiwania. Dziecko uczy się poprzez zdobywanie doświadczeń, dlatego nauczyciel powinien zadbać, aby pole jego doświadczeń było z jednej strony jak najbogatsze, $\mathrm{z}$ drugiej jemu bliskie, zapewniające poczucie bezpieczeństwa. Uczniowie samodzielnie poszukują wiedzy, ją uporządkowują i szukają sposobów jej zastosowania, przez co stają się badaczami, a nauczyciel jest ich facylitatorem. Taka strategia uczenia daje znacznie większe możliwości uczniom z lekką niepełnosprawnością intelektualną nie tylko na opanowanie materiału, ale także na włączenie się w przestrzeń szkolnego życia społecznego.

Przykładem metody pracy w aktywizującej strategii kształcenia jest metoda projektów, która charakteryzuje się największą interaktywnością, a przy tym łączy inne metody i techniki uczenia się. Me-

Olsztyn 2000; R. Michalak, Aktywizowanie ucznia edukacji wczesnoszkolnej, Wyd. Nauk. UAM, Poznań 2004; A. Nalaskowski, Szanse szkoty z wyboru: studium eksploracyjne, Wyd. Adam Marszałek, Torun 1995.

4 A. Brzezińska, Refleksje w działalności nauczyciela, [w:] A. Brzezińska, D. Klus-Stańska, A. Strzelecka, O nowe podejście w ksztatceniu nauczycieli, MEN, Warszawa 1999.

${ }^{5}$ H.R. Schaffer, Social Development, Blackwell Publishers, Oxford 1998, s. 235. 
toda ta już od 1917 r. jest stosowana w Stanach Zjednoczonych, chociaż wcześniejsze wzmianki sięgają pedagogów z XIX i XX w. (m.in. H.W. Kilpatrick, J. Dewey, J.A. Stevenson). Pojęcie projektu na początku było związane z wszelką działalnością uczniowską natury praktycznej, nastawioną na wykonanie pracy zwieńczonej ostatecznym produktem. Zmiana definiowania projektu nastąpiła na skutek filozofii i pedagogiki J. Deweya. Zgodnie z jego koncepcją szkołę tradycyjną miało zastąpić nauczanie oparte na zasadzie "metody projektów". Zamiast podania usystematyzowanej wiedzy podporządkowanej realizacji podstawy programowej, poszatkowanej na zakresy poszczególnych przedmiotów, uczeń miał samodzielnie zacząć poszukiwać wiedzy. Zgodnie z nowymi założeniami podstawowym zadaniem edukacji było nawiązywanie do indywidualnych doświadczeń dziecka w kontekście najnowszych osiągnięć nauki i techniki, determinujących przemiany zachodzące $\mathrm{w}$ środowisku. Główną przesłanką było kształtowanie aktywnej postawy badacza wobec otoczenia, uczenie samodzielności w myśleniu i rozwiązywaniu problemów oraz rozwijanie zainteresowań ucznia.

Obecnie metoda projektów jest metodą nauczania, która opiera się na aktywizującej strategii nauczania. Pozwala na wybór aktywności dzieciom o różnym poziomie rozwoju, pobudza do myślenia, uczy zastosowania nowo nabytej wiedzy w praktyce oraz dzielenia się informacjami z innymi, kształtując tym samym kompetencje komunikacyjne i społeczne. Największe znaczenie przypisuje się intencjonalności uczenia się oraz rozwijania umiejętności uczenia się jako kapitału do przyszłego rozwoju. Metoda projektów umożliwia uczenie poprzez działanie, bezpośrednie polisensoryczne doświadczanie, co w szczególności podnosi poziom efektywności nauczania dzieci z lekką niepełnosprawnością intelektualną. „Projekt stanowi swoisty «kręgosłup» doświadczeń edukacyjnych dzieci i nauczycieli. U ich podstaw leży głębokie przekonanie, że uczenie się poprzez działanie ma wielką wartość, a dyskusje w grupie oraz powrót do wcześniejszych pomysłów i doświadczeń to najlepszy sposób na zdobywanie i poszerzanie wiedzy"?. Dlatego właśnie wybór tematu powinien być przemyślany, ale przede wszystkim 
musi być zależny od zainteresowań dzieci i odnosić się do ich doświadczeń życiowych, dzięki czemu podnosi ich poziom motywacji i emocjonalnego zaangażowania w chęć zdobywania nowych wiadomości i umiejętności. Nauczyciel nie wybiera tematu, tylko go negocjuje wspólnie z uczniami. Jak określa to J.H. Helm i L.G. Katz ${ }^{6}$, nauczyciel obserwuje aktywność badawczą dziecka, która determinuje jego kolejne działania zgodne z jego zainteresowaniami i możliwościami. Rolą nauczyciela jest włączenie $\mathrm{w}$ te działania treści z zakresu poszczególnych edukacji (np. matematycznej, językowej, muzycznej itd.) określonych w podstawie programowej. Metoda projektów ma jednak swoją strukturę. Każdy projekt składa się z trzech etapów:

Etap I - początek projektu - w którym dokonywany jest wybór tematu, analiza wyjściowego stanu wiedzy i umiejętności dzieci, tworzenie przez nauczyciela, wraz z dziećmi, siatki pojęciowej związanej z tematem (powiązanie przez nauczyciela siatki z założeniami programowymi) oraz formułowanie pytań i hipotez.

Etap II - realizacji projektu - to czas aktywności badacza, czyli samodzielnego zdobywania wiedzy, doświadczeń, głównie poprzez szukanie odpowiedzi na pytania wcześniej sformułowane w obrębie realizowanej tematyki projektu.

Etap III - zakończenia projektu - na które składa się podsumowanie zdobytej wiedzy i nowych umiejętności, wzajemne dzielenie się tym kapitałem. Na podstawie uzyskanych informacji przeprowadzana jest analiza projektu (weryfikacja stawianych przez dzieci hipotez) oraz ocena realizacji celów, ogólne podsumowanie projektu i prezentacja uzyskanych wyników ${ }^{7}$.

Podsumowując, metoda projektów pomimo swojej struktury, która spełnia jedynie rolę porządkującą, ma charakter badawczy. Dziecko w sposób holistyczny uczestniczy w projekcie, angażując się intelektualnie, emocjonalnie, społecznie i fizycznie. Dziecko samodzielnie $\mathrm{w}$ nim stawia pytania, poszukuje odpowiedzi i działa,

6 Tamże, s. 17.

7 Tamże, s. 24-25. 
czerpiąc radość z samodzielnego poznawania. Nauczyciel zakreśla pewne ramy oraz pomaga $\mathrm{w}$ poszukiwaniu rozwiązań i potrzebnych materiałów. Taka duża samodzielność i indywidualność w zdobywaniu wiedzy stwarza bardzo dobrą perspektywę zapewniającą uczniowi z lekką niepełnosprawnością intelektualną optymalne warunki uczenia się zgodne $\mathrm{z}$ jego potrzebami i możliwościami. A co najważniejsze - strategia projektowa pozwala na odniesienie sukcesu każdemu dziecku, ponieważ dopiero materiały zgromadzone przez wszystkie dzieci w klasie, bez względu na stopień trudności, tworzą całość pozwalającą zamknąć projekt. W realizacji projektu nie ma znaczenia poziom rozwoju dziecka, ponieważ liczy się każdy jego uczestnik, każdy stanowi ogniwo budujące zwartą całość. Taki sposób pracy zespołu klasowego w znacznie większej mierze stwarza przestrzeń przyjazną inkluzji, pozwalającą każdemu dziecku na włączenie się w życie społeczne klasy.

W związku z korzyściami płynącymi z zastosowania metody projektów postanowiono przeprowadzić badania, których celem było wskazanie, na ile ta metoda jest znana i wykorzystywana przez nauczycieli oraz na ile nauczyciele postrzegają ją jako wspierającą edukację dzieci ze specjalnymi potrzebami edukacyjnymi, w tym z lekką niepełnosprawnością intelektualną.

W badaniach uczestniczyło 60 nauczycieli szkół podstawowych ogólnodostępnych z województwa wielkopolskiego. Badanie zostało przeprowadzone metodą sondażu diagnostycznego za pomocą kwestionariusza ankiety. Grupę badanych nauczycieli stanowili nauczyciele pracujący $\mathrm{w}$ nauczaniu początkowym.

Okazało się, iż 30\% badanych nauczycieli nie zna metody projektów. Pośród 70\% (42 os.) nauczycieli deklarujących znajomość tej metody zaledwie 57\% (24 os.) wykorzystuje ją w swojej pracy, z tego tylko raz w semestrze $87,5 \%$ (21 os.). 12,5\% (3 os.) badanych stwierdziło, iż wykorzystują metodę projektów bardzo często. Jak wynika z zaprezentowanych danych, nauczyciele $\mathrm{w}$ bardzo niewielkim stopniu korzystają w swojej pracy $\mathrm{z}$ metody projektów. Nauczyciele deklarujący znajomość metody projektów podali trudności w jej realizacji (tab.). 
Tabela. Opinie nauczycieli o trudnościach w realizacji metody projektów

\begin{tabular}{|l|c|c|}
\hline \multirow{2}{*}{ Trudności w realizacji metody projektów } & \multicolumn{2}{|c|}{ Badani nauczyciele } \\
\cline { 2 - 3 } & $N(42)$ & {$[\%]$} \\
\hline Dyscyplina & 21 & 50 \\
\hline Kontrolowanie efektów pracy uczniów & 30 & 71,4 \\
\hline Ocena pracy ucznia & 29 & 69 \\
\hline Praca w grupie & 17 & 40 \\
\hline Praca z kartami pracy, podręcznikiem & 26 & 61,9 \\
\hline Przyzwyczajenia & 20 & 47,6 \\
\hline Realizacja programu & 32 & 76,2 \\
\hline Samodzielność uczniów & 19 & 45,2 \\
\hline Selekcja materiału & 12 & 28,6 \\
\hline Środki materialne & 16 & 38 \\
\hline
\end{tabular}

Na podstawie uzyskanych wyników można postawić tezę, że dominującą trudnością pracy metody projektów jest realizacja programu nauczania. Nauczyciele w swoich odpowiedziach argumentowali to głównie faktem, iż muszą realizować treści programowe, a projekty zabierają zbyt dużo czasu. Metoda projektu była przez nich traktowana głównie jako metoda aktywizująca, wykorzystywana w formie nagrody lub atrakcji, a nie jako metoda kształcenia. Drugi rodzaj trudności, na który najczęściej zwracali uwagę nauczyciele, to brak kontroli nad efektami pracy uczniów. Twierdzili oni, iż stosując metodę projektów, nie widzą, jak angażują się poszczególni uczniowie w realizację zadań, przez co uważają, że część dzieci nie pracuje, tylko czeka, aż grupa wykona za nich zadanie. Z powodu braku widoczności efektów działań poszczególnych dzieci wynikała kolejna podawana przez nauczycieli trudność - brak możliwości oceny dziecka. Nauczyciele uważali, iż pracy grupowej nie można ocenić sprawiedliwie. Następna ujawniana trudność to połączenie realizacji projektu z wypełnianiem kart pracy. Nauczyciele w większości nie dostrzegali możliwości realizacji kart pracy podczas projektu, natomiast obawiali się krytyki ze strony rodziców, spowodowanej po- 
wstaniem braków w wypełnianiu podręczników. Badani określali również metodę projektów jako metodę, która burzy dyscyplinę w klasie, to jest dzieci zaczynają się głośno zachowywać, chodzą po klasie i później trudno im wrócić do ustalonego porządku. Część nauczycieli uważała, iż ten brak dyscypliny wpływa negatywnie na koncentrację dzieci, co przekłada się na niższą efektywność nauczania. Nauczyciele jako trudność w pracy z wykorzystaniem metody projektów wymieniali także przyzwyczajenia, które rozumieli tak naprawdę jako dyscyplinę w klasie. Uważali, iż zarówno dzieci, jak i nauczycieli są przyzwyczajeni do pewnego rytmu pracy $\mathrm{w}$ klasie, a jego zmiana powoduje chaos, który zmniejsza efektywność nauczania. Badani wskazywali też na problem samodzielności poznawczej uczniów. Twierdzili, iż uczniowie nie potrafią samodzielnie szukać wiedzy, nie są do tego zmotywowani, przez co praca projektami nie wychodzi. Innym podawanym argumentem była niska umiejętność pracy w grupie. Nauczyciele uważali, iż dzieci podczas realizacji projektu pracują wybiórczo. Wiedzę poszukują tylko niektórzy uczniowie, a reszta grupy czeka, aż zadanie zostanie wykonane. Niektórzy badani twierdzili, iż dzieci w nauczaniu początkowym są jeszcze za małe do takiej pracy grupowej. Dla niektórych nauczycieli przeszkodą w realizacji metody projektów był brak środków materialnych. Najrzadziej podawanym argumentem, dotyczącym wykorzystania metody projektów w procesie kształcenia, były trudności w selekcji materiału, czyli co powinno być realizowane podczas projektu. Argumenty podawane przez badanych nauczycieli w wielu przypadkach ukazują brak zrozumienia podstawowych założeń pracy za pomocą tej metody, szczególnie w obszarze samodzielności ucznia i roli nauczyciela.

Nauczyciele na pytanie, czego potrzebowaliby do pracy metodą projektów, w 42\% odpowiadali, że dodatkowego czasu. To znów pokazuje, iż nie widzą możliwości pracy tą metodą jako metodą realizującą program nauczania. 30,9\% nauczycieli deklarowało, iż potrzebują bardziej elastycznych programów nauczania, a 23,8\% konspektów, pomysłów na realizację projektów. Natomiast 11,9\% badanych wskazywało na współpracę z rodzicami i innymi nauczy- 
cielami. Pojedyncze osoby wymieniły również dodatkowe wyposażenie sali, dostęp do autobusu.

W związku z faktem, iż przez większość nauczycieli metoda projektów jest traktowana jako atrakcja w pracy $z$ dziećmi, a nie jako metoda kształcenia, nie dziwi fakt, iż 76,2\% nauczycieli znających metodę projektów nie wykorzystuje jej do pracy z dziećmi ze specjalnymi potrzebami edukacyjnymi, w tym z dziećmi z lekką niepełnosprawnością intelektualną. 23,8\% (10 os.) badanych zadeklarowało, że wykorzystuje projekty do aktywizowania tych dzieci. Na pytanie, czy stosują metodę projektów do pracy z dziećmi ze specjalnymi potrzebami edukacyjnymi, w tym z dziećmi z lekką niepełnosprawnością intelektualną, w celu wyrównywania kompetencji poznawczych, twierdząco odpowiedziały zaledwie dwie osoby $(4,8 \%)$, a w celu wyrównywania kompetencji społecznych trzy osoby $(7,1 \%)$. Przedstawione wyniki pozwalają na konkluzję, iż nauczyciele nie widzą w metodzie projektów możliwości wsparcia funkcjonowania dzieci ze specjalnymi potrzebami edukacyjnymi, w tym dzieci z lekką niepełnosprawnością intelektualną.

Nauczyciele na pytanie, jak chcieliby wykorzystać metodę projektów do pracy z dziećmi ze specjalnymi potrzebami edukacyjnymi, w tym z dziećmi z lekką niepełnosprawnością intelektualną, w 38\% odpowiedzieli, iż nie widzą jej specjalnego zastosowania, tylko w taki sam sposób jak u innych dzieci. Zastosowanie jej w celu podnoszenia motywacji dzieci do nauki zgłosiło $23,8 \%$ badanych, a do integracji 19\% respondentów. Zgodnie z uzyskanymi wynikami, nauczyciele nie tylko nie stosują metody projektów do pracy z dziećmi ze specjalnymi potrzebami edukacyjnymi, w tym z dziećmi z lekką niepełnosprawnością intelektualną, ale także nie dostrzegają możliwości jej wykorzystania w takim aspekcie. Analizując wyniki badań, istotna wydaje się odpowiedź na pytanie: Czy nauczyciele nie widzą możliwości zastosowania metody projektów do tworzenia płaszczyzny inkluzji z racji na niską wiedzę i doświadczenie w pracy tą metodą, czy brak chęci jej zastosowania? Próbując odpowiedzieć na to pytanie, warto przedstawić raport z badań $(\mathrm{Za})$ trudne, bo trzeba myśleć, z którego wynika, iż na lekcjach w klasach III szkół podstawowych: 
- $60 \%$ - 27 min to czas przeznaczany na sprawdzanie wiedzy uczniów (w szkołach miejskich (SM) 59\%, a w szkołach wiejskich (SW) 61,1\%), to jest odpytywanie, wykonywanie podobnych typowych zadań, odpowiadanie na typowe pytania nauczyciela;

- przez 24,2\% (10,89 min) czasu uczniowie słuchają nauczyciela, który mówi, czyta, prowadzi pogadankę (w SM 21,5\%, a w SW $27,3 \%)$, kiedy rola uczniów jest ograniczona do odpowiedzi na konkretne, zamknięte pytania;

- przez 2,4\% czasu uczniowie dyskutują oraz rozmawiają z nauczycielem i kolegami (w SM 1,3\%, w SW 3,7\%). Dyskusja wystąpiła na 18 spośród 148 obserwowanych zajęć (na 8 zajęciach na 70 w SW oraz 10 na 78 w SM). Nie pojawiła się natomiast na zajęciach w 27 szkołach na 40 (14 SW oraz 13 SM);

- przez 2,7\% czasu uczniowie są aktywni twórczo/badawczo (w SM 3\%, w SW 2,3\%). Aż w 29 szkołach (16 SW i 13 SM) nie pojawił się fragment zajęć, w którym uczniowie mieliby okazję do faktycznego twórczego działania. Pewne przejawy dziecięcej twórczości dały się zauważyć podczas 15 zajęć (7 w SW (na 70) oraz 8 w SM (na 78)). Na pozostałych 133 obserwowanych zajęciach działania uczniów były absolutnie i wyłącznie odtwórcze;

- przez 2,4\% czasu uczniowie biorą udział w grach i zabawach dydaktycznych (w SM 1\%, w SW 4\%). Gry i zabawy pojawiły się na 20 zajęciach spośród 178 (17 razy w SW i tylko 3 razy w SM).

Brak wiary w możliwości ucznia to jedna $\mathrm{z}$ najbardziej typowych cech obserwowanych zajęć. W ślad za nią podążają kolejne zjawiska - dominujący i dużo mówiący nauczyciel, a w rezultacie mało aktywne intelektualnie dzieci powtarzające schematy narzucone przez nauczyciela $\mathrm{i}$ - w efekcie - niezbyt zainteresowane wydarzeniami dziejącymi się na lekcji ${ }^{8}$.

Biorąc pod uwagę raport $\mathrm{z}$ badań (Za) trudne, bo trzeba myśleć i przedstawione wyniki badań własnych, można stwierdzić, iż nauczy-

${ }^{8}$ M. Dąbrowski, (Za) trudne, bo trzeba myśleć? O efektach nauczania matematyki na pierwszym etapie edukacyjnym, IBE, Warszawa 2013, s. 206-216. 
ciele w większości pracują zgodnie ze strategią kształcenia transmisyjnego. W dużej mierze nie znają i nie pracują przy użyciu strategii aktywizujących. Brak wiedzy i doświadczenia w tym obszarze, a także pewne przyzwyczajenia $\mathrm{w}$ rozumieniu roli nauczyciela utrudniają podjęcie nauczania metodą projektów jako wiodącą metodą realizującą podstawę programową. W związku z przedstawionymi korzyściami, jakie niesie pracą z wykorzystaniem metody projektów w szczególności dla dzieci ze specjalnymi potrzebami edukacyjnymi, w tym dzieci z lekką niepełnosprawnością intelektualną, warto zastanowić się nad popularyzacją tej metody. Na pewno wymagałoby to dostosowania jej do uwarunkowań społeczno-kulturowych naszego społeczeństwa. W Polsce trudności w zastosowaniu tej metody wiążą się z nastawieniem naszej edukacji na realizację programu (kompetencji wynikających z poszczególnych edukacji), a nie nabywanie kompetencji do uczenia się, posługiwania się wiedzą. Rola nauczyciela, który ma szczegółowo zaplanowane swoje zajęcia, a podczas nich przekazuje wiedzę i kontroluje jej przyswajanie, tylko w niewielkim stopniu pozwala na twórczą aktywność dziecka. Metoda projektów zmienia te podejście. Nauczyciel staje się osobą wspierającą rozwój dziecka. Projekt angażuje dziecko i jego najbliższe otoczenie, obejmując wiedzę z różnych dziedzin oraz kształtując różnorodne umiejętności, dlatego metoda projektów ma takie istotne znaczenie dla holistycznego rozwoju dziecka oraz podniesienia efektywności i jakości jego edukacji. Natomiast samodzielność i indywidualność w zdobywaniu wiedzy, a zarazem praca $\mathrm{w}$ grupie, charakterystyczna dla tej metody, może stanowić efektywną płaszczyznę włączenie dzieci ze specjalnymi potrzebami edukacyjnymi, w tym z lekką niepełnosprawnością intelektualną, w przestrzeń życia szkolnego.

\section{Bibliografia}

BĄBKA J., Psychospołeczne aspekty efektywności edukacji w systemie integracyjnym, [w:] Z. Kazanowski, D. Osik-Chudowolska (red.), Integracja osób niepetnosprawnych w edukacji i interakcjach społecznych, Wyd. UMCS, Lublin 2003. 
Brantley A., HuEbner E.S., NAGle R.J., Multidimensional Life Satisfaction Reports of Adolescents With Mild Mental Disabilities, „Mental Retardation” 2002, Vol. 40, No. 4.

BRZEZIŃSKA A., Refleksje w działalności nauczyciela, [w:] A. Brzezińska, D. Klus-Stańska, A. Strzelecka, O nowe podejście w ksztatceniu nauczycieli, MEN, Warszawa 1999.

CHODKOWSKA M., Socjopedagogiczne problemy edukacji integracyjnej dzieci z obciażeniami biologicznymi i środowiskowymi, WSP TWP, Warszawa 2004.

CHRZANOWSKA I., Uczeń z upośledzeniem umysłowym w szkole ogólnodostępnej, [w:] W. Dykcik, C. Kosakowski, J. Kuczyńska-Kwapisz (red.), Pedagogika specjalna szansa na realizacje potrzeb osób z odchyleniami od normy, Wyd. Nauk. PTP, Olsztyn-Poznań-Warszawa 2002.

ĆWIRYNKAŁO K., Pozycja socjometryczna uczniów niepetnosprawnych a postawa nauczycieli wobec integracji, [w:] Z. Kazanowski, D. Osik-Chudowolska (red.), Integracja osób niepetnosprawnych w edukacji i interakcjach społecznych, Wyd. UMCS, Lublin 2003.

DĄBROWSKI M., (Za) trudne, bo trzeba myśleć? O efektach nauczania matematyki na pierwszym etapie edukacyjnym, IBE, Warszawa 2013.

GAJDZICA Z., O wychowaniu i kształceniu dzieci o specjalnych potrzebach edukacyjnych w szkole ogólnodostępnej, [w:] J. Wyczesany, Z. Gajdzica, Uwarunkowania edukacji i rehabilitacji uczniów o specjalnych potrzebach rozwoju, Wyd. Nauk. Akademii Pedagogicznej, Kraków 2006.

GŁODKOWSKA J., Poznanie ucznia szkoty specjalnej, WSiP, Warszawa 1999.

GoŁęBNIAK D., TEUSz G., Edukacja poprzez język. O całościowym uczeniu się, Wyd. CDN, Warszawa 1999.

Helm J.H., KATZ L.G., Mali badacze metoda projektu w edukacji elementarnej, Wyd. CDN, Warszawa 2003.

KLUS-STAŃSKA D., Konstruowanie wiedzy w szkole, Wyd. UWM, Olsztyn 2000.

KWIECIŃSKI Z., Nieobecne dyskursy, Wyd. Nauk. UMK, Toruń 1991.

LIPIŃSKA J., ROGOŻA A., Stosunek $i$ zachowanie dzieci petnosprawnych wobec dzieci niepetnosprawnych w klasach integracyjnych, [w:] Z. Kazanowski, D. Osik-Chudowolska (red.), Integracja osób niepetnosprawnych w edukacji i interakcjach społecznych, Wyd. UMCS, Lublin 2003.

LIPIŃSKA-LOKŚ J., Psychospołeczne funkcjonowanie uczniów niepetnosprawnych w klasach integracyjnych, [w:] J. Bąbka (red.), Człowiek niepetnosprawny w różnych fazach życia, Wyd. „Żak”, Warszawa 2004.

MichalaK R., Aktywizowanie ucznia edukacji wczesnoszkolnej, Wyd. Nauk. UAM, Poznań 2004.

NALASKOWSKI A., Szanse szkoty z wyboru: studium eksploracyjne, Wyd. Adam Marszałek, Torun 1995.

SADOWSKA S., Jakość życia uczniów z niepetnosprawnością intelektualna w stopniu lekkim, Oficyna Wydawnicza „Impuls”, Kraków 2006a. 
SADOWSKA S., Szkolne stosunki interpersonalne w ocenach zadowolenia uczniów z niepetnosprawnością intelektualną w stopniu lekkim, „Szkoła Specjalna” 2006b, nr 4.

SCHAFFER H.R., Social Development, Blackwell Publishers, Oxford 1998.

SZUMSKI G., Wokót edukacji włączającej. Efekty kształcenia uczniów z niepetnosprawnościa intelektualna w stopniu lekkim w klasach specjalnych, integracyjnych i ogólnodostępnych, Wyd. APS, Warszawa 2010.

ZAMKOWSKA A., Psychospoteczne i edukacyjne funkcjonowanie ucznia z upośledzeniem umystowym w stopniu lekkim w szkole ogólnodostępnej, [w:] Z. Gajdzica (red.), Wspólne $i$ swoiste zagadnienia edukacji i rehabilitacji osób z upośledzeniem umystowym, Oficyna Wydawnicza „Humanitas”, Sosnowiec 2008. 